\title{
Analisis Data Berat Badan dan Panjang Bayi dengan Alat Ukur Panjang dan Berat Badan Bayi Berbasis Arduino
}

\author{
Bayu Wahyudi ${ }^{1)}$, Deny Julian Adella ${ }^{2)}$, dan Muhammad Ulin Nuha ABA ${ }^{3)}$ \\ ${ }^{1,2,3)}$ Akademi Teknik Elektro Medik Semarang \\ 1,2,3) Jl. Kolonel Warsito Sugiarto, 172 Km 2, RW.5, Sadeng, Kec. Gn. Pati, Kota Semarang, Jawa Tengah 50222 \\ e-mail: bayuwahyudi@atemsemarang.ac.id ${ }^{1)}$, denijulianadella19@ gmail.com ${ }^{2)}$, \\ ulinnuhaaba@atemsemarang.ac.id ${ }^{3)}$
}

\begin{abstract}
Monitoring the nutritional status of infants at this time is mostly still using the manual method, by looking at anthropomeric standard books so that nutritional monitoring takes longer and is less practical. Babies need nutritional status based on age, weight, length of the baby (baby's height), and sex of the baby. To find out the nutritional condition of the baby, the author wants to develop a measurement tool for weight and length of the baby with the output data in Microsoft Excel. This study aims to design a baby's weight and length measurement tools with data output at Microsoft Excel and perform a function test. The process of detection in infants using ultrasonic sensors that serves to determine the height or length of the baby's body and load cell sensors to determine the baby's weight, then the LCD (Liquid Crystal Display) which displays the results of ultrasonic sensors and load cell sensors and Arduino Uno. The results of this study are an infant weight and height measurement tool with an arduino uno-based anthropometric index method with 2 ultrasonic sensors as height and length counters, and 1 load cell sensor as a weight calculator for infants that will later be displayed on the LCD screen.
\end{abstract}

Keywords: Weight and height, Anthropometry, Arduino uno

\section{ABSTRAK}

Pemantauan status gizi bayi saat ini sebagian besar masih menggunakan cara manual, dengan melihat buku standar antropomer sehingga pemantauan gizi membutuhkan waktu yang lebih lama dan kurang praktis. Bayi memerlukan status gizi yang berdasarkan umur, berat badan, Panjang bayi (tinggi bayi), dan jenis kelamin bayi. Untuk mengetahui kondisi gizi bayi tersebut, maka penulis ingin melakukan pengembangan alat ukur berat badan dan panjang bayi dengan output data di microsoft excel. Penelitian ini bertujuan untuk merancang alat ukur berat badan dan panjang bayi dengan output data di microsoft excel serta melakukan uji fungsi. Proses pendeteksi pada bayi dengan menggunakan sensor ultrasonik yang berfungsi untuk mengetahui tinggi atau panjang badan bayi dan sensor load cell untuk mengetahui berat badan bayi, Kemudian LCD (Liquid Crystal Display) yang menampilkan hasil dari sensor ultrasonik dan sensor load cell dan arduino uno. Hasil penelitian ini adalah sebuah alat pengukur berat badan dan tinggi badan bayi dengan metode indeks antropometri berbasis arduino uno dengan 2 sensor ultrasonik sebagai penghitung tinggi dan panjang, dan 1 sensor load cell sebagai penghitung berat badan pada bayi yang nantinya akan di tampilkan pada layar LCD

Kata kunci: $P \& O$, Panel Surya, $M P P T$.

\section{Pendahuluan}

A ntropometri adalah pengukuran pada diri pasien/klien tentang dimensi, komposisi dan/atau pembangkakan tubuh [1]. Tujuan penelitian pengukuran antropometri, yaitu mengetahui kekekaran otot, kekekaran tulang, ukuran tubuh secara umum, panjang tungkai dan lengan. Salah satu parameter yang diukur dalam pemeriksaan antropometri adalah berat badan dan tinggi badan. Antropometri biasanya disajikan dalam bentuk indeks, seperti berat badan menurut umur $(\mathrm{BB} / \mathrm{U})$, tinggi badan menurut umur $(\mathrm{TB} / \mathrm{U})$ dan berat badan menurut tinggi badan $(\mathrm{BB} / \mathrm{TB})$ [2].

Salah satu yang memerlukan data berat badan dan tinggi badan yaitu bayi. Bayi memerlukan status gizi yang berdasarkan umur, berat badan, Panjang bayi (tinggi bayi), dan jenis kelamin bayi, sehingga dapat mengetahui kondisi gizi bayi tersebut. Biasanya setiap bayi akan didata menggunakan (KMS) untuk mengetahui kenaikan atau penurunan dari berat badan bayi. Pengukuran ini dilakkukan setiap satu bulan sekali. Seorang user akan lebih mudah jika data. Sehingga user tidak perlu repot-repot menulis secara manual data KMS yang didapat [3] .

Oleh karena itu, maka penulis ingin melakukan pengembangan alat ukur berat badan dan panjang bayi dengan output data kartu menuju sehat di microsoft exel. Dari latar belakang ini penulis ingin membuat alat ukur berat badan dan panjang bayi dengan output data kartu menuju sehat di microsoft exel yang akan dituangkan dalam kaya tulis ilmiah dengan judul "Rancang Bangun Alat Ukur Berat Badan Dan Panjang Bayi Dengan Output Data Kartu Menuju Sehat Di Microsoft Exel". Penulis berharap hal ini akan mempermudah user dalam melakukan pengisian kartu menuju sehat (KMS) yang biasanya digunakan di posyandu [4]. 


\section{KAJIAN PUSTAKA}

\section{A. Antropometri}

Tujuan penelitian pengukuran antropometri, yaitu mengetahui kekekaran otot, kekekaran tulang, ukuran tubuh secara umum, panjang tungkai dan lengan. Data ukuran tubuh manusia dalam sisi tingginya yang diukur dalam keadaan murni tinggi badan dari tumit hingga ujung kepala tanpa ada benda lain yang ikut terukur. Tinggi badan di Indonesia menggunakan Arduino UNO yang memungkinkan siapa saja melakukan pembuatan prototipe suatu rangkaian elektronika yang berbasis mikrokontroler dengan mudah dan cepat. Secara lebih khusus, papan Arduino berbasis mikrokontroler yang dikeluarkan oleh perusahaan Atmel. Sebagai contoh, Arduino Uno menggunakan mikrokontroler Atmega328P [5]. Arduino UNO memuat semua yang dibutuhkan untuk menunjang mikrokontroler, mudah menghubungkamya ke sebuah komputer dengan sebuah kabel USB atau mensuplainya dengan sebuah adaptor AC ke DC atau menggunakan untuk memulainya [6]

Arduino Uno berbeda dari semua board Arduino sebelumnya, Arduino UNO tidak menggunakan chip driver FTDI USB-to-serial. Sebaliknya, fitur-fitur Atmega16U2 (Atmega8U2 sampai ke versi R2) diprogram sebagai sebuah pengubah USB ke serial. Revisi 2 dari. HWB ke ground, yang membuatnya lebih mudah untuk diletakkan ke dalam DFU mode [7]. Revisi 3 dari board Arduino UNO memiliki fitur-fitur baru sebagai berikut yang ditunjukkan pada Gambar 1 :

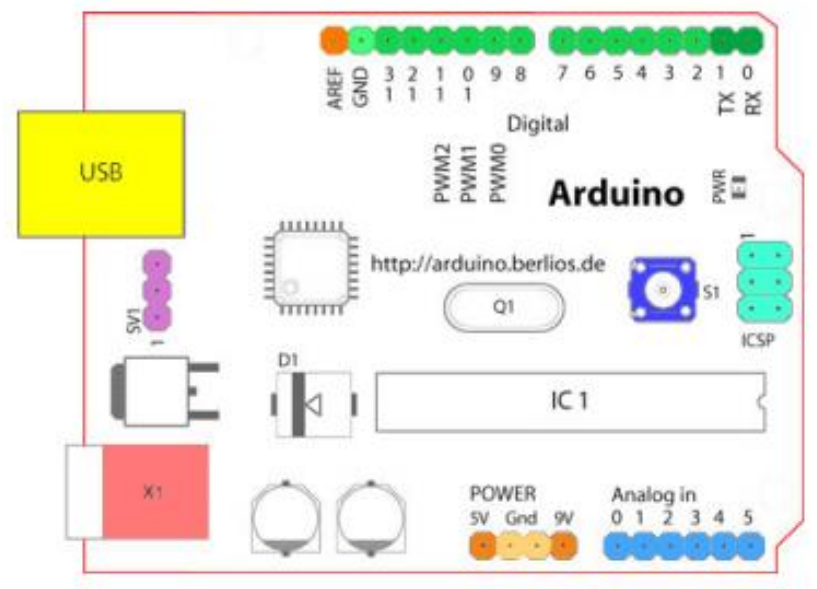

Gambar 1 Rangkaian Arduino UNO

\section{B. Load Cell}

Sensor Strain Gauge (Load cell) adalah komponen utama pada sistem timbangan digital, dimana tingkat keakurasian timbangannya bergantung dari jenis load cell yang dipakai. Sensor load cell, apabila diberi beban pada inti besi maka nilai-nya akan berubah yang dikeluarkan melalui tiga buah kabel, dimana dua kabel sebagai eksitasi dan satu kabelnya lagi sebagai sinyal keluaran ke kontrolnya. dan jembatan wheatstone [8], . Berikut ini merupakan gambar dari loadcell yang akan ditunjukkan dalam gambar 2 .

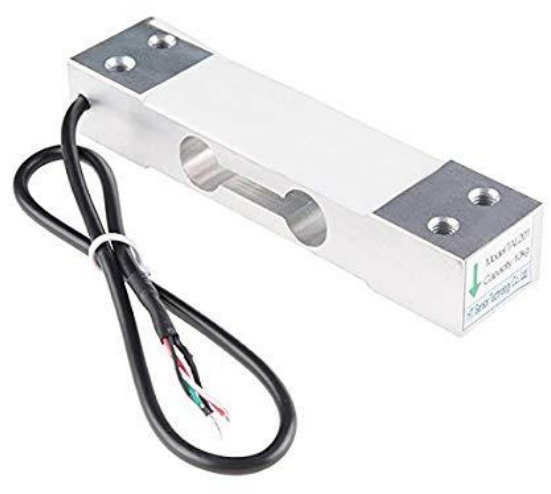

Gambar 2 Loadcell

\section{Sensor Ultrasonik}

Sensor ultrasonik terdiri dari sebuah chip pembangkit sinyal $40 \mathrm{KHz}$, sebuah speaker ultrasonik, dan sebuah mikropon ultrasonik. Speaker ultrasonik mengubah sinyal $40 \mathrm{KHz}$ menjadi suara sedangkan mikropon ultrasonik berfungsi untuk mendeteksi pantulan suaranya. Frekuensi kerjanya adalah pada daerah di atas gelombang suara dari $40 \mathrm{KHz}$ hingga $400 \mathrm{KHz}$ [9]. Cara kerja sensor ultra dapat diilustrasikan seperti pada Gambar 3 di bawah ini.

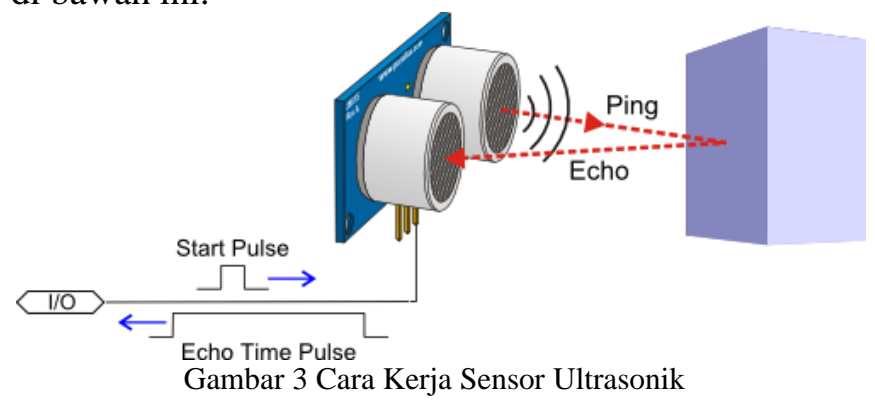

Sensor ultrasonik adalah sensor yang bekerja berdasarkan prinsip pantulan gelombang suara dan digunakan untuk mendeteksi keberadaan suatu objek tertentu di depannya. Sehingga Ping digunakan untuk mengirimkan gelombang dan Echo akan menerima pantulan gelombang tersebut.

\section{Rangkaian Power Supply}

Rangkaian power supply merupakan rangkaian penyuplai / penyedia tegangan untuk semua rangkaian yang membutuhkan tegangan. Pada penelitian ini penulis menggunakan adaptor charger hand phone yang tegangan keluarannya sebesar +5.1 volt dengan arus sebesar 1 ampere yang akan cukup untuk menyuplai semua rangkaian [10].

\section{Metode Penelitian}

Pada jenis penelitian ini yaitu merancang alat ukur berat badan dan panjang bayi dengan output data kartu menuju sehat di microsoft exel. Penelitian ini diharap bisa dimanfaatkan oleh user untuk melakukan pengisian data kartu menuju sehat (KMS). Hasil penelitian ini 
bukanlah suatu penemuan baru, akan tetapi merupakan aplikasi baru dari penelitian dan percobaan terdahulu

\section{A. Perencanaan Sistem Alat}

Berikut ini merupakan perencanaan blok diagram yang akan digunakan untuk membuat alat ukur berat badan dan panjang bayi dengan output data kartu menuju sehat di microsoft exel yang akan diperlihatkan pada gambar sebagai berikut

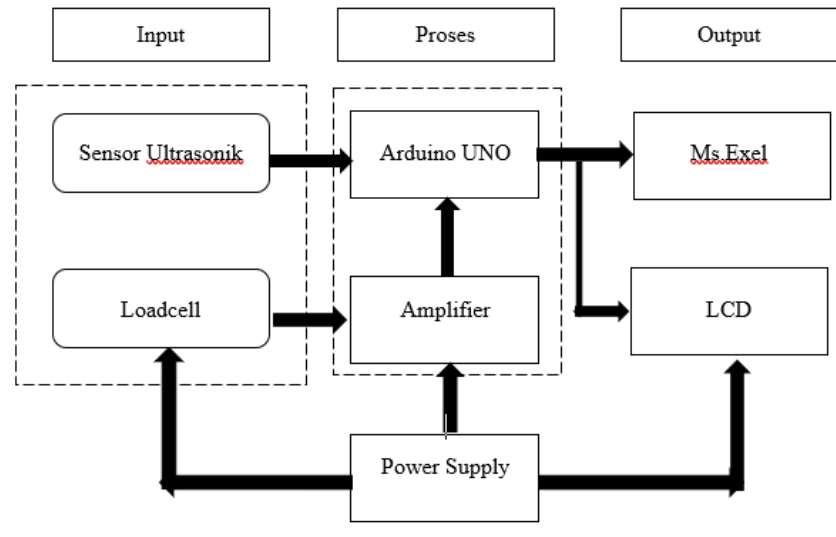

Gambar 4 Diagram Blok Alat

Keterangan:

Input

Pada bagian input terdiri dari:

a. Sensor Ultrasonik

Sensor ini digunakan untuk mengukur panjang bayi dengan memanfaatkan pantulan gelombang ultrasonik.

b. Loadcell

Sensor ini digunakan untuk mengukur berat badan bayi dimana hasilnya akan dikuatkan oleh modul HX711, serta modul HX711 ini berperan sebagai ADC sebelum menuju ke arduino.

Proses

Didalam proses mikrokontroler arduino mengendalikan semua proses pada alat ukur berat badan dan panjang bayi dengan output data kartu menuju sehat di microsoft exel. Ada juga modul HX711 yang berfungsi sebagai ADC - analog to digital converter 24bit yang akan mengkonversi nilai resistansi dari jembatan Wheatstone menjadi, nilai ini akan berbanding lurus dengan berat benda yang ditimbang. Selain itu juga ada aplikasi PLX-DAQ yang akan memasukkan data berat badan dan tinggi badan ke microsoft exel.

Output

Output dari alat ini adalah data kartu menuju sehat (KMS) yang akan masuk ke dalam microsoft exel untuk memudahkan user saat pengambilan data serta pengisiannya dan tampilan LCD agar orang tua bayi dapat melihat juga secara langsung hasil dari pengukuran berat badan dan panjang bayinya.

Flowchart Penelitian

Dalam pembuatan alat ukur berat badan dan panjang bayi dengan output data kartu menuju sehat di microsoft exel ini diperlukan perencanaan dan proses yang teliti agar dihasilkan suatu alat yang baik dan mampu berfungsi dengan baik. Berikut adalah gambar tahapan dalam pembuatan alat yang ditunjukkan pada Gambar Berikut:

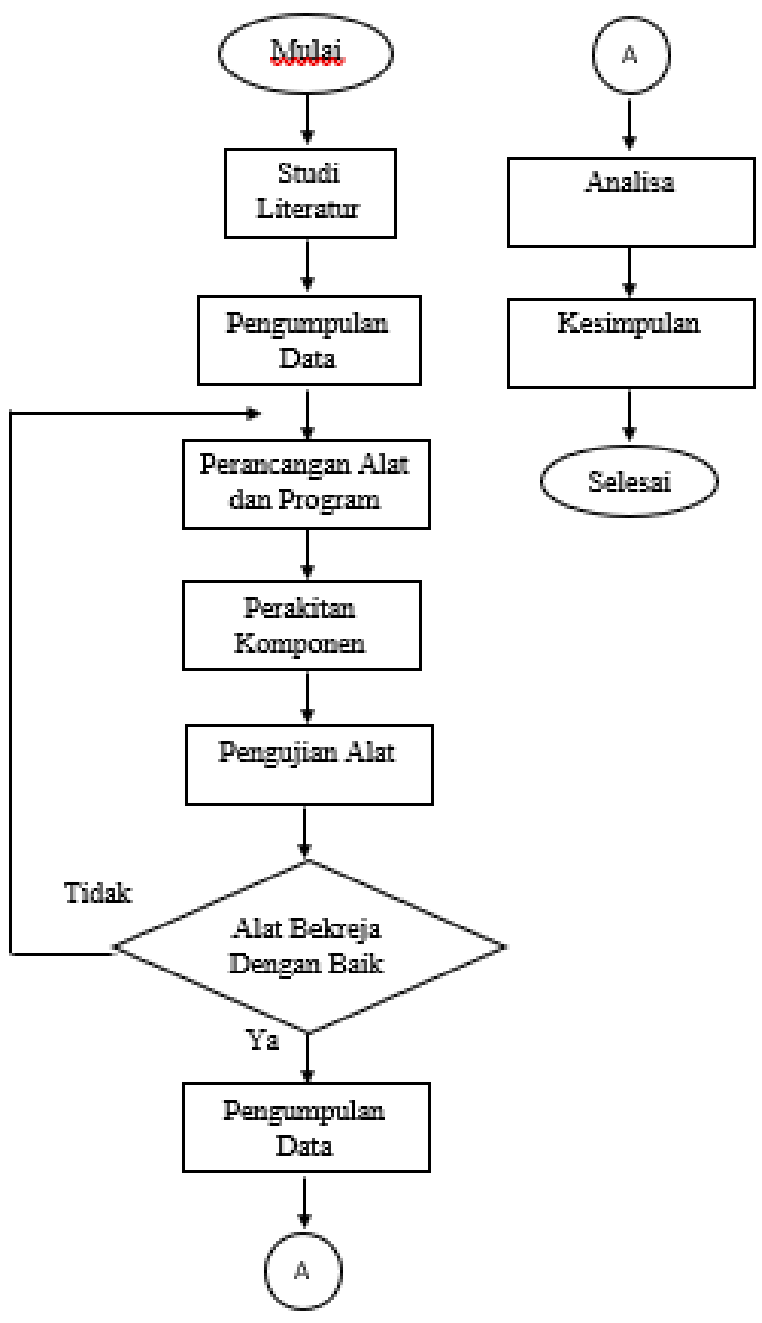

Gambar 5 Diagram Blok Alat

Perencanaan Desain Alat

Dalam pembuatan alat ukur berat badan dan panjang bayi dengan output data kartu menuju sehat di microsoft exel ini penulis melakukan perencanaan desain alat sebagai berikut yang akan ditunjukkan pada gambar berikut.

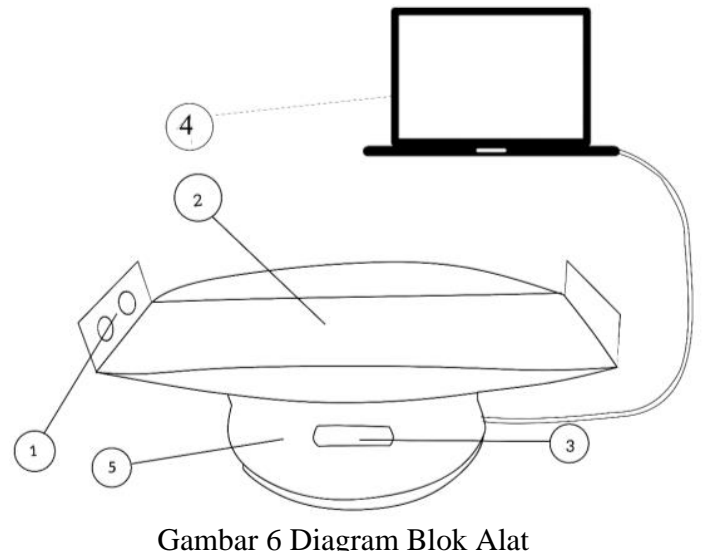

Gambar 6 Diagram Blok Alat 


\section{HASIL DAN PEMBAHASAN}

Hasil pengukuran dan perbandingan alat yang dibuat penulis dengan alat meteran dan timbangan analog. Pengukuran dilakukan pada 4 bayi yang berbeda. Hasil tersebut tertera pada Tabel 1 sebagai berikut :

Tabel 1 Hasil Pengukuran dan Perbandingan

\begin{tabular}{|c|c|c|c|c|c|}
\hline \multirow[t]{2}{*}{$\begin{array}{l}\text { Sampe } \\
1 \mathrm{Ke}\end{array}$} & \multirow[t]{2}{*}{$\begin{array}{l}\text { Pengukura } \\
\mathrm{n}\end{array}$} & \multicolumn{2}{|c|}{$\begin{array}{l}\text { Alat berbasis } \\
\text { arduino }\end{array}$} & \multicolumn{2}{|c|}{$\begin{array}{c}\text { Timbangan } \\
\text { Analog dan } \\
\text { Meteran }\end{array}$} \\
\hline & & $\begin{array}{l}\text { Panjan } \\
\text { g Bayi } \\
(\mathrm{cm})\end{array}$ & $\begin{array}{l}\text { Bera } \\
\mathrm{t} \\
\text { Bayi } \\
(\mathrm{kg})\end{array}$ & $\begin{array}{l}\text { Panjan } \\
\text { g Bayi } \\
(\mathrm{cm})\end{array}$ & $\begin{array}{l}\text { Bera } \\
\mathrm{t} \\
\text { Bayi } \\
(\mathrm{kg})\end{array}$ \\
\hline & 1 & 38 & 3.21 & 38 & 3.2 \\
\hline & 2 & 38 & 3.13 & 38 & 3.2 \\
\hline & 1 & 43 & 4.89 & 44 & 4.8 \\
\hline & 2 & 43 & 4.61 & 44 & 4.8 \\
\hline & 1 & 55 & 7.15 & 57 & 7.2 \\
\hline & 2 & 55 & 7.46 & 57 & 7.2 \\
\hline & 1 & 64 & 9.58 & 63 & 9.6 \\
\hline & 2 & 64 & 9.61 & 63 & 9.6 \\
\hline
\end{tabular}

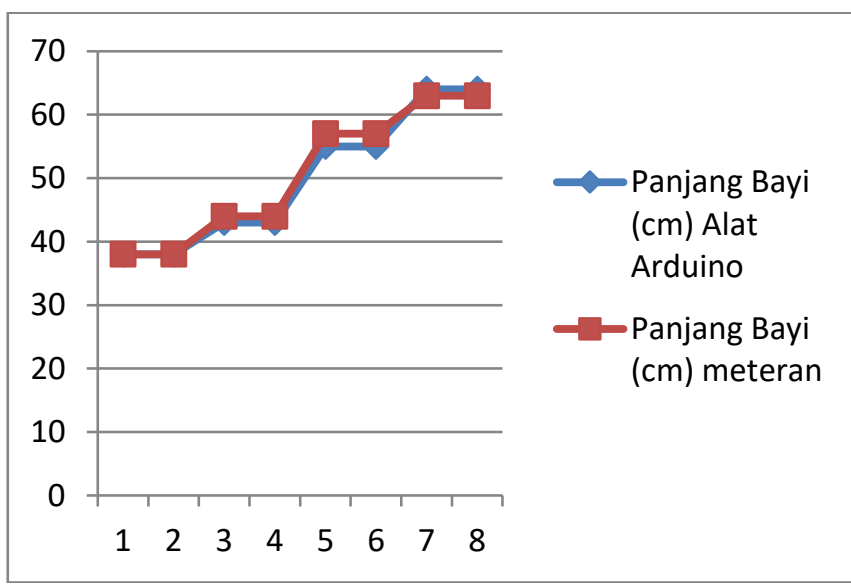

Gambar 7 Grafik Perbandingan panjang bayi dengan alat berbasis arduino dengan meteran

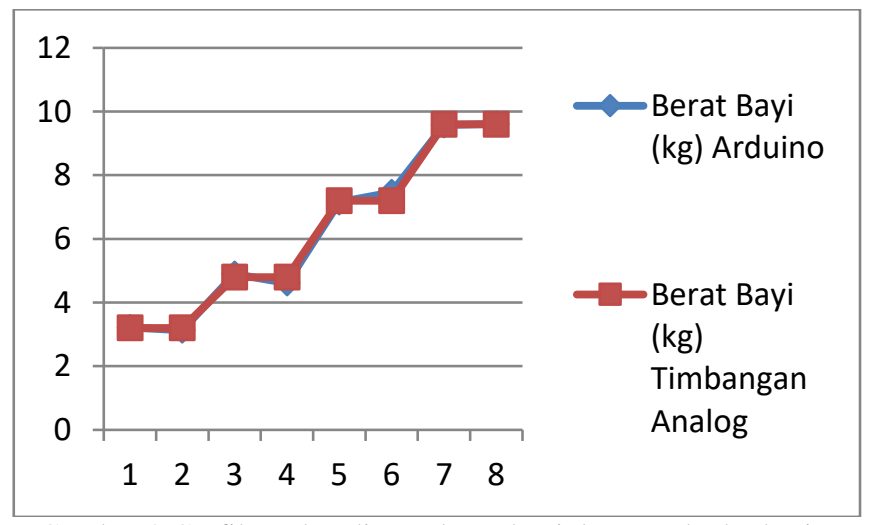

Gambar 8 Grafik Perbandingan berat bayi dengan alat berbasis arduino dengan timbangan analog

Dari grafik dapat kita ambil kesimpulan bahwa hasil pengukuran alat tidak jauh berbeda dengan hasil pengukuran dengan alat ukur standar. Persentase perbandingan alat rancang bangun penulis dan alat ukur konvensional didapatkan dari perhitungan dengan rumus sebagai berikut:

$\%$ Perbandingan Panjang Bayi $=$ $\mid$ Hasil Ukur-Hasil Meteran $\mid x 100 \%$

$$
\text { Hasil Meteran }
$$

$\%$ Perbandingan Berat Bayi $=$

$\underline{\mid \text { Hasil Ukur-Hasil Meteran Analog } \mid \times 100 \%}$ Hasil Timbangan analog

Pada pengukuran sampel ke-1 dilakukan pada bayi sepanjang $63 \mathrm{~cm}$ dan seberat 9,6 kg. Jadi perhitungan perbandingan pada pengukuran panjang dan berat bayi pada sampel pertama adalah sebagai berikut:

$\%$ Perbandingan Panjang Bayi $=$ $\underline{\mid \text { Hasil Ukur-Hasil Meteran } \mid x 100 \%}$

$=\frac{|64-63| \times 100 \%}{63}$

$=1.5 \%$

$\%$ Perbandingan Berat Bayi $=$

|Hasil Ukur-Hasil Meteran Analog| $x$ 100\% Hasil Timbangan analog

$=\frac{\mid \text { Hasil Ukur }- \text { Hasil Meteran } \mid \times 100 \%}{\text { Hasil Meteran }}$

$=0.1 \%$

Pada pengukuran sampel ke-2 dilakukan pada bayi sepanjang $38 \mathrm{~cm}$ dan seberat $3,2 \mathrm{~kg}$. Jadi perhitungan perbandingan pada pengukuran panjang dan berat bayi pada sampel pertama adalah sebagai berikut:

$\%$ Perbandingan Panjang Bayi = |Hasil Ukur-Hasil Meteran $\mid x 100 \%$

$$
\text { Hasil Meteran }
$$

$=\frac{|64-63| \times 100 \%}{63}$

$=1.5 \%$

$\%$ Perbandingan Berat Bayi =

|Hasil Ukur-Hasil Meteran Analog |x 100\% Hasil Timbangan analog

$=\frac{\mid \text { Hasil Ukur }- \text { Hasil Meteran } \mid \times 100 \%}{\text { Hasil Meteran }}$

$=0.1 \%$

Pada pengukuran sampel ke-3 dilakukan pada bayi sepanjang $57 \mathrm{~cm}$ dan seberat $7,2 \mathrm{~kg}$. Jadi perhitungan perbandingan pada pengukuran panjang dan berat bayi pada sampel pertama adalah sebagai berikut:

$\%$ Perbandingan Panjang Bayi $=$ $\underline{\mid \text { Hasil Ukur-Hasil Meteran } \mid \times 100 \%}$ Hasil Meteran

$=\frac{|64-63| \times 100 \%}{63}$

$=1.5 \%$

$\%$ Perbandingan Berat Bayi =

|Hasil Ukur-Hasil Meteran Analog | $x 100 \%$ Hasil Timbangan analog

$=\frac{\mid \text { Hasil Ukur-Hasil Meteran } \mid \times 100 \%}{\text { Hasil Meteran }}$

$=0.1 \%$ 
Pada pengukuran sampel ke-4 dilakukan pada bayi sepanjang $44 \mathrm{~cm}$ dan seberat $4,8 \mathrm{~kg}$. Jadi perhitungan perbandingan pada pengukuran panjang dan berat bayi pada sampel pertama adalah sebagai berikut:

$\%$ Perbandingan Panjang Bayi = |Hasil Ukur-Hasil Meteran $\mid \times 100 \%$ Hasil Meteran

$=\frac{|64-63| \times 100 \%}{63}$

$=1.5 \%$

$\%$ Perbandingan Berat Bayi $=$

$\underline{\mid \text { Hasil Ukur-Hasil Meteran Analog } \mid \times 100 \%}$ Hasil Timbangan analog

$=\frac{\mid \text { Hasil Ukur }- \text { Hasil Meteran } \mid \times 100 \%}{\text { Hasil Meteran }}$

$=0.1 \%$

Dari hasil perbandingan yang telah dilakukan penulis, alat menunjukkan hasil panjang bayi dan berat bayi dengan selisih nilai dari alat rancangan penulis dan alat yang sudah jadi menunjukan rata-rata persentase perbandingannya adalah $1,8 \%$ pada pengukuran panjang bayi dan persentase perbandingan alat $0,9 \%$ dari ratarata pengukuran berat bayi.

\section{KESIMPULAN}

Setelah melakukan pembuatan alat ini, mulai dari studi pustaka, perencanaan, pengambilan data dan Analisa, penulis dapat mengambil kesimpulan sebagai berikut:

1. Penulis menggunakan mikrokontroler ARDUINO UNO sebagai pengolahan data dari sensor ultrasonic untuk mengukur panjang bayi dan sensor load cell untuk mengukur berat bayi, kemudian ditampilkan di Microsoft Excel dengan parameter data kartu menuju sehat (KMS). Selain itu data juga ditampilkan di LCD 16x2 sebagai opsi lain jika hanya melakukan pengukuran tanpa memasukkan data menuju KMS.

2. Menurut perbandingan dan analisa dari alat yang dibuat penulis dan alat yang sudah ada, hasil persentase perbandingan alat dari pengukuran panjang bayi menunjukkan angka $0 \%$ sampai 3,5\% dan hasil persentase perbandingan alat dari pengukuran berat bayi menunjukkan angka $0,1 \%$ sampai $1,5 \%$. Dari hasil yang diperoleh, alat yang dibuat penulis menunjukkan kondisi yang normal.

\section{Daftar Pustaka}

[1] N. Noviardi and A. Aperta, "Perancangan Aplikasi Timbangan Bayi pada Posyandu dengan Standar Antropometri WHO 2005 Menggunakan Arduino Uno R3, Ms.Visual Studio. Net 2010 dan MySQL," CoreIT, vol. 3, no. 1, p. 1, Jan. 2018, doi: 10.24014/coreit.v3i1.2188.

[2] T. H. A. Cahyono and E. A. Suprayitno, "Alat Ukur Berat Badan, Tinggi Badan dan Suhu Badan di Posyandu
Berbasis Android," ELINVO, vol. 3, no. 1, pp. 31-38, Jul. 2018, doi: 10.21831/elinvo.v3i1.19456.

[3] W. A. Akbar and H. H. Rachmat, "Rancang Bangun Sistem Pengukur Massa Tubuh dan Panjang Badan Elektronik Terintegrasi untuk Evaluasi Gizi Balita," ELKOMIKA, vol. 6, no. 1, p. 125, Apr. 2018, doi: 10.26760/elkomika.v6i1.125.

[4] W. A. A. Kustiana and H. H. Rachmat, "Perancangan Dan Realisasi Box Alat Ukur Panjang Badan Balita Elektronik Berbasis Personal Computer (PC)," JETT, vol. 4, no. 2, p. 551, Dec. 2017, doi: 10.25124/jett.v4i2.1121.

[5] D. Y. Apriawan, "Alat Ukur Panjang Dan Berat Badan Balita Untuk Menentukan Kategori Status Gizi Berbasis Arduino Uno," vol. 07, p. 8, 2018.

[6] R. Nurhasanah, P. C. Nugraha, and H. G. Ariswati, "Politeknik Kesehatan Kementerian Kesehatan Surabaya," p. 11.

[7] Akademi Teknik Elektro Medik Semarang, B. Wahyudi, M. Miftahudin, Akademi Teknik Elektro Medik Semarang, I. Firdaus, and Lampung University, "Rancang Bangun Mobile Infant Warmer dengan Menggunakan Pemanas DC," J. Teori Apl. Fis., vol. 7, no. 2, pp. 145152, Jul. 2019, doi: 10.23960/taf.v7i2.2143.

[8] R. D. Kinanthi, "Politeknik Kesehatan Kementrian Kesehatan Surabaya," p. 9.

[9] I. P. T. Indrayana, T. Julian, and K. Triyana, "Pengujian Akuisisi Data sensor Ultrasonik HC-SR04 dengan Mikrokontroler Atmega 8535," vol. 6, p. 6, 2017.

[10] B. Wahyudi, K. A. Cipta, and M. U. Nuha ABA, "Rancang Bangun Modul Kontrol Alat Terapi Batu Ginjal (ESWL) Dengan Mikrokontroler AT-Mega16 Berdasarkan Sistem Pernapasan Manusia," elektrika, vol. 12 , no. 2, p. 48 , Oct. 2020, doi: 10.26623/elektrika.v12i2.2267. 